\section{PM-009５歳児の目標志向性について（1） 一好奇心調査をふまえて一}

○宮代こず急, 石川 隆行 ${ }^{1}$, 稲川 知美吕, 磯 裕子2.\# (1宇都宮大学, ${ }^{2}$ 宇都宮大学教育学部附属幼稚園) キーワード： 5 歳児, 目標志向性, 好奇心

稲垣（1977）は, 子どもの好奇心の関連要因について検討する中で, 教 師による好奇心評定と事物に対する好奇心測定の相関が低いことを示し， 前者は効率的な探索やすぐれた成果を引き起こす結果志向的な好奇心を 反映している一方で，後者は過程志向的な好奇心をあらわしているので はないかと論じている。そこで本研究では，5歳児を対象としてこれら $2 つ の$ 好奇心を測定するとともに，それぞれが子どもの目標志向性とと のように関連しているかについて検討を行った。1回目調査では, 稲垣 （1977）に従い子どもの好奇心を 5 つの観点から評価するよう，クラス担 任教諭（2 名）へそれぞれ依頼した。また 5 歳児 59 名を対象とした以下 の調查を行った。調查者は 3 種の玩具を 1 つずつ子どもに手渡し, 行動 を 2 分間ずつ観察した。約 3 か月後の 2 目調查は上記の 59 名のうち 9 名 を抽出し対象とし同様の調查を行った。1 回目および 2 回目のいずれの 調查に扔いても, 先行研究の結果と同様, 2 つの好奇心間の関連は認め られなかった（1 回目調查デー夕の相関分析結果 $r=.158, p=.232 ; 2$ 回目 調查 $r=-.227, p=.558)$ 。また 1 回目の教師による好奇心評定得点には目 標志向性による差が見られた $(t(57)=2.108, p=.039)$ 。

\section{PM-011＼cjkstart複合感情が俳句の美的評価に及ぼす 影響一畏敬とノスタルジアの観点か ら一}

○櫃割 仁平 ${ }^{1}$, 野村 理朗 $^{1}$

(京都大学)

キーワード：俳句，美的評価，複合感情

芸術において美と感情の関係はアリストテレスの時代から主題であっ た. Menninghaus, et al. (2017) は特にネガティブ感情と美の包括的なモ デルを提唱し，その中で畏敬の念やノスタルジア等の複合感情がそれら の統合を担いうると論じた。詩歌は, 古代から主要な芸術の1つである が，心理学領域では音楽や映画の知見と比して限定的である。他方で，詩 歌，とりわけ 17 文字の俳句は統制された題材で，実験で感情反応を直接 的に測定するのに適しており，本研究は，俳句を用いてネガティブ感情 が美に繋がる心理プロセスを検討する。参加者 267 名 $\left(\mathrm{M}_{\mathrm{age}}=40.0\right.$ ，女性 171名）は23句の俳句をそれぞれ俳句の感情洒，感情評定，畏敬，ノス夕 ルジア, 美的評価等の観点から評価し，個人特性に関する質問紙にも回 答した。その結果, 感情が美的評価に及ほすす畏敬の媒介効果が, ネガティ ブな俳句に確認されたのに対して，ポジティブではみられなかった。対 称的に, ノスタルジアの媒介効果はネガティブ俳句よりポジティブ俳句 で強く見られた。こうした結果は，俳句の感情価によって媒介する複合 感情に差異があること, 特にネガティブ感情から生じる美の感覚は畏敬 の念により媒介されることを示した。

連絡先 E-mail：hitsuwari.jimpei.74x@st.kyoto-u.ac.jp
$\mathrm{PM}-010$

5 歳児の目標志向性について（2） 一エピソード調査をふまえて一

○石川 隆行 ${ }^{1}$, 宮代こず总 ${ }^{1}$, 坂本 修子2.\# $^{2 . \#}$

(1宇都宮大学, ${ }^{2}$ 宇都宮大学附属幼稚園)

キーワード：5歳児, 目標志向性, エピソード調查

本調查は，5歳児の目標志向性について検討した。高崎（2003）によ れば, 目標志向性とはパフォーマンスゴール（自分の能力の評洒に関心 があり，難しい課題を避ける傾向）とラーニングゴール（自分の能力を 伸ばすことに関心があり，努力や挑戦を続ける）に区分される。本調查 では高崎（2003）を参考に鉄棒場面とお絵かき場面を作成し，各場面に ついてどちらが嬉しいかを 5 歳児に尋ねた。また, 担任教諭 2 名から 5 歳児個別の目標志向性に関するエピソードを収集した。各場面の目標志 向性（パフォーマンスゴール／ラーニングゴール）について, クラス別, 性別の $\chi^{2}$ 検定を実施したところ有意差は認められなかった $\left(\right.$ クラス $\chi^{2}{ }_{(1)}=$ $0.929, n . s$. ; 性別 $\chi_{(1)}^{2}=0.049, n . s$.)。しかしながら， 5 歳览個別のエピ ソードから, 例えば, 両場面にてパフォーマンスゴール傾向である 5 歳 児の 1 人は，自分から友だちと関わらうとすることが少なく，いつも担 任教諭の近くで教諭の言動や友だちへの言葉かけを気にかける姿が多い ことが明らかになった。今後, 担任教諭が設定する環境や声掛けに着目 し，幼児期の目標志向性を明らかにしたい。

\section{PM-012＼cjkstart公正世界信念と妬み感情が他者の不 幸に対するシャーデンフロイデと同 情および不幸の相応性評定に与える 影響}

○星野 諒太 ${ }^{1}$, 谷井 淳一2

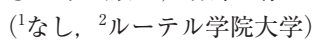

キーワード：妬み，公正世界信念，シャーデンフロイデ

本研究では, 良性と覀性の妬み感情と公正世界信念シャーデンフロイ デの関連について検討した。本調查ではクラウドワークス社のモニター を対象に質問紙調查を行い528名の有効回答を得た。質問紙の内容は, 日 本語版 BeMaS（澤田・藤井，2016） と公正世界信念尺度（村山・ 三浦, 2015）を回答させた後，本研究にて作成した他者が不幸に陥る架空の場 面を読んでもらった。この場面は，ストーリーの主人公が誠実に生きて きたか否かという違いがある 2 パターンを作成した。そして，それに対 する反応を他者の不幸に関する感情尺度（澤田，2008）と本研究にて作 成した相応性尺度で測定した。そこで得られたデー夕に対して重回帰分 析を行ったところ, 不公正世界信念が強いほど悪性妬み得点が高い $(\beta=.26, \mathrm{p}<.01)$ 。誠実に生きてきた人物が不幸に陥った際，究極的公正 世界信念が強い場合，男性はシャーデンフロイデが喚起されやすく $(\beta=.50, \mathrm{p}<.01)$ ，女性は同情が喚起されやすい $(\beta=.39, \mathrm{p}<.01)$ 。誠実に 生きてきた人物が不幸に陥った際, 内在的公正世界信念が強い場合, 男 性は同情が喚起されやすく $(\beta=.39, \mathrm{p}<.01)$ ，女性は同情が喚起されにく くなる $(\beta=.-20, \mathrm{p}<.05)$ 。といった傾向が示された。

連絡先 E-mail : hoshino.ryota.31020@gmail.com 